\title{
Monitoring of Nutrient Status in an Alluvial Soil Amended with Different Inorganic and Organic Fertilizers
}

\author{
Tapas Kumar Halder ${ }^{1 *}$, Ajit Kumar Dolui ${ }^{2}$ and Dipankar Saha ${ }^{3}$ \\ ${ }^{1}$ Govt. of West Bengal, India \\ ${ }^{2}$ Department. of Agricultural Chemistry and Soil Science, \\ Institute of Agricultural Science, University of Calcutta, India \\ ${ }^{3}$ Bidhan Chandra Krishi Viswavidyalaya, Mohanpur, Nadia, West Bengal, India \\ *Corresponding author
}

\section{A B S T R A C T}

Keywords

FYM, Inorganic fertilizers,

Available nutrient in soil

\section{Article Info}

Accepted:

28 April 2020

Available Online:

10 May 2020
An incubation study was conducted to monitor the changes in nutrient status of a typic haplaquept soil treated with organic and different inorganic fertilizers including $\mathrm{S}$ and $\mathrm{B}$. Results revealed that balanced usage of organic and inorganic fertilizers plays a critical role in sustainable agriculture. Addition of FYM increased the organic carbon content and availability of nutrients over soil alone and soil treated with only inorganic fertilizers. Results further revealed that the beneficial effects of FYM is recorded when it is applied with $\mathrm{S}$ and B. Again application of higher doses of S and B along with organic and inorganic fertilizer intensified the availability of nutrients in soil.

\section{Introduction}

Higher food production needs higher amount of plant nutrients. Use of inorganic fertilizers has increased considerably to meet the higher nutrient requirements of the present day which creates imbalance in nutrient supply leading to decline in soil fertility, crop productivity and sustainability. Balanced nutrition based on soil test value is the key to sustain and improve soil productivity. A suitable combination of secondary and micronutrients is an important factor that affects the productivity of the crops. Organic resources play a dominant role in soil properties through their short-term effects on nutrient supply and longer-term contribution to soil organic matter (SOM) formation (Palm et al., 2001). In order to supply all the nutrients to soil in adequate amount and to maintain its good health, it is necessary to use organic sources like FYM in combination with fertilizers. They not only supply macronutrients but also meet the demand of micro nutrients, besides improving soil health (Arbad and Ismail, 2011). Boron is a micro nutrient which is deficient in most of the soils of West Bengal, plays a vital role in 
augmenting growth and yield of mustard (Naik et al., 2015). The present experiment was, therefore, conducted to study the influence of FYM, S and B on soil fertility build up as well as to monitor the changes in nutrient status of an alluvial soil.

\section{Materials and Methods}

Composite soil sample was collected from a farmer's field situated at Gotra mouza in Chakdah block in the district of Nadia West Bengal. The soil has been classified as Typic Haplaquept by National Bureau of Soil Science (NBSS and LUP). The field was generally cultivated for rice-mustard cropping sequence. The soils were collected prior to rice cultivation.

The collected soil sample was air-dried, ground in wooden pestle and mortar and passed through 80 mesh seive. The soil sample was analyzed for different physical, chemical and microbiological parameters following standard analytical procedures and the data are presented in Table 1. The FYM used as treatment material contain $\mathrm{N}, \mathrm{P}_{2} \mathrm{O}_{5}$, $\mathrm{K}_{2} \mathrm{O}, \mathrm{S}$ and $\mathrm{B}$ about $0.58 \%, 0.26 \%, 0.40 \%$, $0.02 \%$ and $2.8 \mathrm{mgkg}^{-1}$.

The laboratory experiment was conducted during December-February 2014-2015 under controlled laboratory conditions. Each pot containing three $\mathrm{kg}$ soils were incubated for a period of ninety days. Arable moisture level (60\% of water holding capacity of the soil) was maintained throughout the incubation study. Loss of moisture due to evaporation was replenished every alternate day by difference in weight. In order to ascertain the effect of added secondary and micronutrients along with NPK fertilizers and FYM, the following six treatment combinations in completely randomized design were adopted. All the treatments are replicated thrice.

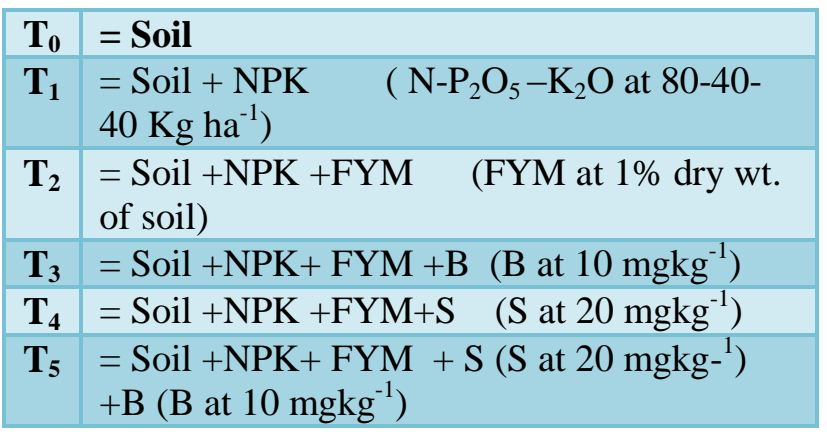

To the allocated pots $\mathrm{N}, \mathrm{P}$ and $\mathrm{K}$ were applied at 80,40 and $40 \mathrm{Kg} \mathrm{ha}^{-1}$ as $\mathrm{N}, \mathrm{P}_{2} \mathrm{O}_{5}$ and $\mathrm{K}_{2} \mathrm{O}$ through urea, single super phosphate and muriate of potash, respectively. Well decomposed FYM was added as treatment material at $1 \%$ dry weight basis. Sulphur was applied through elemental sulphur (95\% puriety) at $20 \mathrm{mgkg}^{-1}$ and Boron was applied through borax $(10.5 \% \mathrm{~B})$ at $10 \mathrm{mg} \mathrm{kg}$ 1. All treatment materials were added to soil as basal on the $1^{\text {st }}$ day of experiment. Samples from each pot were analyzed on the $15^{\text {th }}, 30^{\text {th }}$, $60^{\text {th }}$ and $90^{\text {th }}$ day of incubation study. Soils are analysed periodically for oxidisable organic carbon, available nitrogen, available phosphorus, available potassium, available sulphur, DTPA extractable $\mathrm{Zn}$ and Microbial Biomass carbon. Different soil parameters were analyzed statistically following the methods of Walter T. Federar (1927) to study the significance of means among treatments at different sampling stages of incubation study.

\section{Results and Discussion}

\section{Exchangeable $\mathrm{NH}_{4}^{+}$}

Changes in the amount of exchangeable $\mathrm{NH}_{4}^{+}$in soil treated with different combinations of inorganic and organic fertilizers are presented in Table 2. Irrespective of treatments, $\mathrm{NH}_{4}{ }^{+}$decreased up to $60^{\text {th }}$ (except $T_{3}$ ) thereafter showed an increasing trend upto $90^{\text {th }}$ day of incubation (except in control, $\mathrm{T}_{0}$ ) (Table 2). The effect of added $\mathrm{N}$ fertilizer is well marked in all the treatments. The decrease in $\mathrm{NH}_{4}{ }^{+}$upto $60^{\text {th }}$ 
day of the experiment is mainly due to the losses through denitrification and volatilization (Burger and Venterea, 2008). Combined application of NPK fertilizers along with FYM and B leads to accumulate highest amount exchangeable $\mathrm{NH}_{4}{ }^{+}$on $15^{\text {th }}$ and $30^{\text {th }}$ day of incubation, whereas on $60^{\text {th }}$ day as well as on $90^{\text {th }}$ day of incubation The increase in exchangeable $\mathrm{NH}_{4}{ }^{+}$is due to spurt in ammonifying micro-organisms under the favorable micro-environment created in soil due to addition of all types of energy materials applied through balanced fertilization (Benbi et al., 2007). Addition of micro nutrient had little effect in increasing exchangeable $\mathrm{NH}_{4}{ }^{+}$content in soil. Statistical analysis of the results revealed that the treatments, stages of sampling as well as their interactions are significant.

\section{Soluble $\mathrm{NO}_{3}^{-}$}

Similar trend of results of soluble $\mathrm{NO}_{3}{ }^{-}-\mathrm{N}$ was observed which was found for changes in exchangeable $\mathrm{NH}_{4}{ }^{+}$in soil (Table 2). Irrespective of stages of sampling, soluble $\mathrm{NO}_{3}{ }^{-}-\mathrm{N}$ increases with integration of FYM along with $\mathrm{S}$ and $\mathrm{B}$. Again, irrespective of treatments, $\mathrm{NO}_{3}{ }^{-}$content remained more or less same in 15 and $30^{\text {th }}$ day of sampling and then decreased slightly (except in treatment $\mathrm{T}_{2}$ ) due to loss only through denitrification (Casy and Clark, 2012). Highest amount of concentration were found on $90^{\text {th }}$ days due to more activity of nitrifying bacteria as well as more $\mathrm{N}$ mineralization (Woldendrop and Laanbrock, 1989) under balanced nutrition system. Data are statistically significant with respect to stages of sampling, treatments.

Table.1 Physical and chemical properties of the soil used for the incubation study

\begin{tabular}{|l|l|l|l|}
\hline $\begin{array}{l}\text { Sl. } \\
\text { No }\end{array}$ & Parameters & Result & Reference Method \\
\hline $\mathbf{1 .}$ & $\mathrm{pH}$ & 7.56 & Jackson, 1973 \\
\hline $\mathbf{2 .}$ & Electrical Conductivity $\left(\mathrm{dsm}^{-1}\right)$ & 0.190 & Jackson, 1973 \\
\hline $\mathbf{3 .}$ & Mechanical Separates & & Piper, 1966 \\
\hline $\mathbf{i )}$ & Sand \% & 16.8 & \\
\hline $\mathbf{i i )}$ & Silt \% & 18.0 & \\
\hline $\mathbf{i i i})$ & Clay \% & 65.2 & USDA, 1975 \\
\hline & Textural class & Clay loam & Schollen Berger and Simon, (1945) \\
\hline $\mathbf{4 .}$ & $\begin{array}{l}\text { Cation exchange capacity } \\
\text { C mol(p+) } \mathrm{kg}^{-1}\end{array}$ & 24.6 & \\
\hline $\mathbf{5 .}$ & Organic carbon $(\%)$ & 0.52 & Walkley and Black, 1934 \\
\hline $\mathbf{6 .}$ & Water holding capacity $(\%)$ & 47.90 & Baruah and Barthakur,1997 \\
\hline $\mathbf{7 .}$ & Total Nitrogen $(\%)$ & 0.088 & Stevenson,1996 \\
\hline $\mathbf{8 .}$ & Available $\left(\mathrm{NH}_{4}^{+}\right)$ & 123.47 & Bremner and Keeney, 1965 \\
\hline $\mathbf{9}$ & Available $\left(\mathrm{NO}_{3}{ }^{-}\right)$ & 24.16 & \\
\hline $\mathbf{1 0}$ & Available phosphorus $\left(\mathrm{kgha}^{-1}\right)$ & 46.34 & Olsen et al.,1954 \\
\hline $\mathbf{1 1}$ & Available potassium $\left(\mathrm{kgha}^{-1}\right)$ & 150.74 & Jackson,1973 \\
\hline $\mathbf{1 2}$ & Available sulphur $\left(\mathrm{mg} \mathrm{kg}^{-1}\right)$ & 6.38 & Chesnin and Yien,1951 \\
\hline $\mathbf{1 3}$ & Available B $\left(\mathrm{mg} \mathrm{kg}^{-1}\right)$ & 0.46 & Wolf, 1971 \\
\hline $\mathbf{1 4}$ & $\begin{array}{l}\text { Microbial biomass carbon } \\
(\mu \text { gkg-1) }\end{array}$ & 95.36 & Joergenson,1995 \\
\hline $\mathbf{1 5}$ & USDA Nomenclature & Typic Haplaquept & USDA,1975 \\
\hline & & & \\
\hline
\end{tabular}


Table.2 Influence of inorganic and organic amendments on changes in availability of different soil parameters

\begin{tabular}{|c|c|c|c|c|c|c|c|}
\hline Treatments & $\begin{array}{c}\text { Incubation } \\
\text { Period } \\
\text { (Days) }\end{array}$ & $\begin{array}{c}\mathrm{NH}_{4}{ }^{+} \\
\mathrm{kgha}^{-1}\end{array}$ & $\begin{array}{c}\mathrm{NO}_{3}^{-} \\
\text {kgha }^{-1}\end{array}$ & $\begin{array}{l}\text { Av. P } \\
\text { Kgha }^{-1}\end{array}$ & $\begin{array}{l}\text { Av. K } \\
\text { Kgha }^{-1}\end{array}$ & $\begin{array}{l}\text { OC } \\
(\%)\end{array}$ & $\begin{array}{c}\text { MBC } \\
\mu \mathrm{g} \mathrm{kg}^{-1}\end{array}$ \\
\hline \multirow[t]{4}{*}{$\mathbf{T}_{0}=$ Soil } & 15 & 176.03 & 38.81 & 64.10 & 184.50 & 0.57 & 111.2 \\
\hline & 30 & 124.06 & 35.08 & 62.63 & 166.10 & 0.59 & 117.06 \\
\hline & 60 & 125.2 & 33.1 & 56.46 & 153.50 & 0.57 & 118.36 \\
\hline & 90 & 113.06 & 34.83 & 53.10 & 139.90 & 0.64 & 122.13 \\
\hline \multirow[t]{4}{*}{$T_{1}=$ Soil + NPK } & 15 & 195.23 & 36.01 & 80.53 & 217.26 & 0.59 & 116.13 \\
\hline & 30 & 122.16 & 40.53 & 81.80 & 239.50 & 0.63 & 127.12 \\
\hline & 60 & 133.2 & 28.1 & 95.26 & 194.00 & 0.71 & 129.23 \\
\hline & 90 & 171.06 & 38.58 & 90.80 & 173.76 & 0.74 & 135.4 \\
\hline \multirow[t]{4}{*}{$\mathrm{T}_{2}=$ Soil $+\mathrm{NPK}+\mathrm{FYM}$} & 15 & 211.63 & 46.01 & 166.46 & 263.40 & 0.56 & 137.83 \\
\hline & 30 & 156.26 & 42.08 & 178.53 & 267.53 & 0.76 & 143.31 \\
\hline & 60 & 176.1 & 50.5 & 164.13 & 218.83 & 0.76 & 141.21 \\
\hline & 90 & 205.16 & 41.08 & 153.26 & 206.73 & 0.8 & 133.42 \\
\hline \multirow[t]{4}{*}{$\mathbf{T}_{3}=$ Soil + NPK + FYM $+B$} & 15 & 233.13 & 46.51 & 160.20 & 255.13 & 0.54 & 131.68 \\
\hline & 30 & 161.26 & 55.03 & 168.66 & 263.30 & 0.82 & 157.56 \\
\hline & 60 & 134.2 & 34 & 156.66 & 223.23 & 0.75 & 148.09 \\
\hline & 90 & 184.96 & 51.48 & 157.33 & 204.50 & 0.83 & 161.23 \\
\hline \multirow[t]{4}{*}{$T_{4}=$ Soil + NPK + FYM $+S$} & 15 & 214.43 & 33.06 & 147.53 & 258.40 & 0.71 & 126.34 \\
\hline & 30 & 151.46 & 38.53 & 154.16 & 264.83 & 0.71 & 141.04 \\
\hline & 60 & 141.1 & 37.5 & 159.16 & 223.30 & 0.71 & 149.42 \\
\hline & 90 & 176.16 & 43.08 & 160.23 & 183.03 & 0.79 & 161.1 \\
\hline \multirow[t]{4}{*}{$\mathbf{T}_{5}=$ Soil + NPK + FYM $+\mathbf{S}+\mathbf{B}$} & 15 & 222.03 & 45.51 & 154.50 & 257.93 & 0.7 & 137.54 \\
\hline & 30 & 230.26 & 38.63 & 160.76 & 256.26 & 0.73 & 157.76 \\
\hline & 60 & 107.1 & 24.15 & 164.96 & 219.93 & 0.76 & 154.1 \\
\hline & 90 & 162.96 & 48.03 & 160.13 & 201.9 & 0.81 & 165.14 \\
\hline $\mathrm{SE}_{\mathrm{m}}(\operatorname{Tr} \times$ Days $)$ & & 0.78 & 0.77 & 0.51 & 0.60 & 0.01 & 0.90 \\
\hline $\mathrm{CD}(\mathrm{P}=\mathbf{0 . 0 5})$ & & 2.20 & 2.19 & 1.46 & 1.70 & 0.02 & 2.55 \\
\hline
\end{tabular}



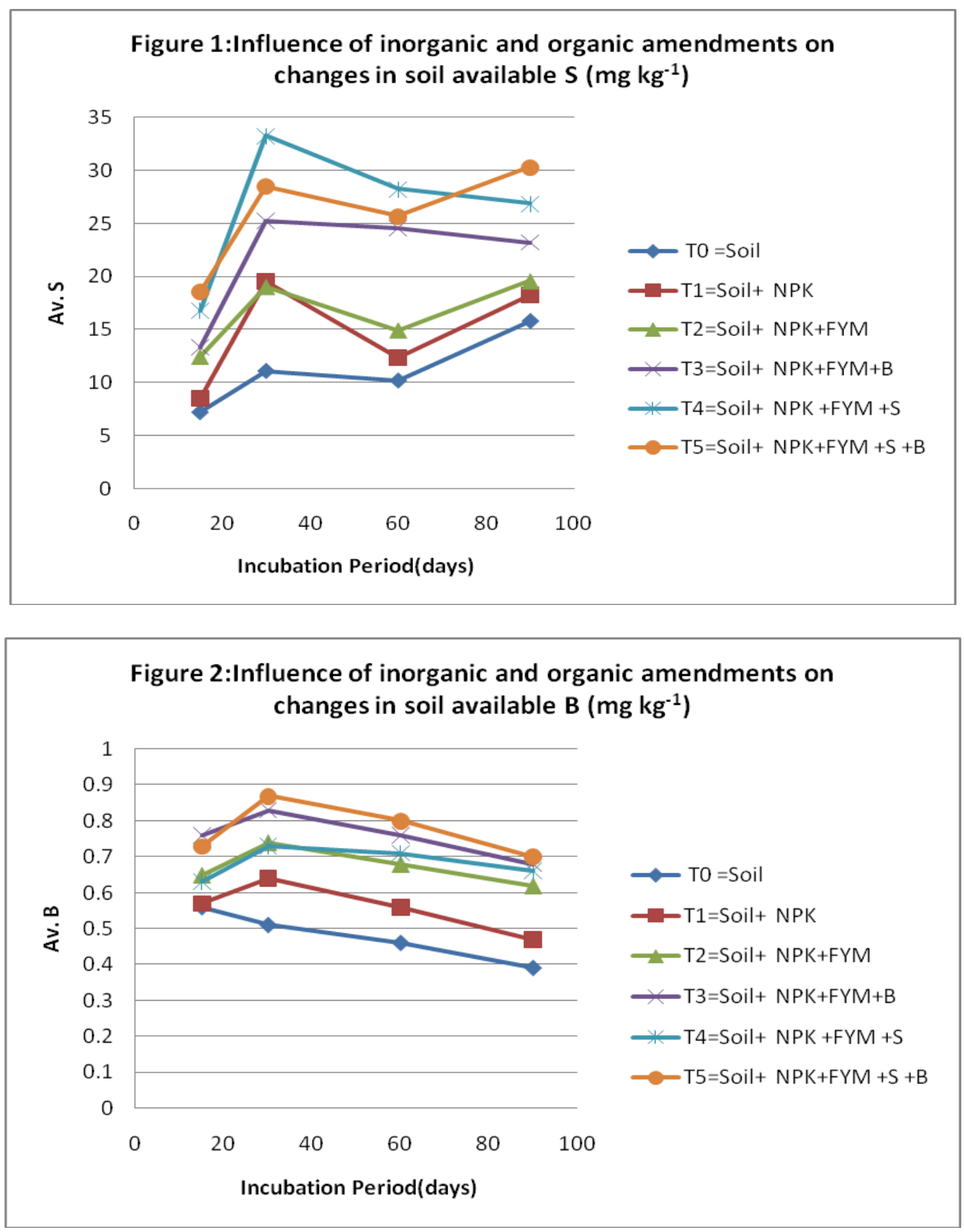

\section{Available P}

Irrespective of treatments (except in control), in general, available phosphorus showed an increasing trend up to $30^{\text {th }}$ then showed an decreasing trend up to $60^{\text {th }}$ day (with $\mathrm{T}_{2}$ and $\mathrm{T}_{3}$ ) and then slightly decreased with $\mathrm{T}_{1}$ and $\mathrm{T}_{2}$ up to the last stage of incubation (Table 2). Highest amount of accumulation of available phosphorus on $30^{\text {th }}$ day of experiment is due to mineralization of organic phosphorus as well as non utilization of available phosphorus by the growing crops. The decrease in available phosphorus at the last stage of incubation in some treatments is due to consumption of available phosphorus by the microorganisms and the conversion of available phosphorus into other inorganic and 
organic form with time (Clark, 1998).The decrease in available phosphorus at the last stage of incubation in some treatments is due to consumption of available phosphorus by the microorganisms and the conversion of available phosphorus into other inorganic and organic form with time (Antil and Singh, 2007). The effect of added treatment materials is very prominent in accumulation of available P. Addition of organic and inorganic fertilizers including micronutrients is essential for the proliferation of P-solubilizing organisms in soil (Buurash, 1997), which in turn increased the available $\mathrm{P}$ content in soil (Fraser, 1994).

\section{Available K}

Table 2 showed that amount of available $\mathrm{K}$ first increased up to $30^{\text {th }}$ day and afterward it decrease up to $90^{\text {th }}$ day in all the treatment except $\mathrm{T}_{3}$. Results in Table 2 further showed that highest amount of available $\mathrm{K}$ are accumulated in treatment $\mathrm{T}_{3}$ in all the sampling stages. This is perhaps due to release of higher amount of available $\mathrm{K}$ from FYM and inorganic source under favorable microbial growth. Similar results were also obtained (Burger and Venterea, 2008).

\section{Organic Carbon}

Changes in the amount of oxidizable organic carbon in soil treated with different combinations of inorganic and organic fertilizers are presented in Table 2. Results revealed that irrespective of treatments, in general, oxidizable organic carbon increased with increase in the period of incubation. The increase in organic carbon is more prominent in organic matter treated systems. FYM increased the organic carbon content in soil. Highest amount of oxidizable organic carbon content is accumulated in soil in $\mathrm{T}_{3}$ closely followed by $\mathrm{T}_{5}$ treatment. Balanced fertilization increased the proliferation of microbial population and its activities in soil The death of these microbes enhances microbial biomass carbon which in turn increases the oxidizable organic carbon content in soil (Sarkar and Singh, 1997). The increase in oxidizable organic carbon with the period of investigation particularly at the last stage is due to increase in number of microorganisms. Decomposition of dead cells of these organisms increased the organic carbon content in soil at the later stage of incubation (Premi, 2003). There were earlier works of (Abraham and Lal, 2003) reported percent increase of organic carbon in the soil due to integration of different nutrient sources. Statistical analysis of the results revealed that the treatments differ significantly among themselves.

\section{Microbial Biomass Carbon}

Irrespective of treatments, microbial biomass carbon increased with increase in the period of incubation (Table 2). The increase in microbial biomass carbon with time is due to proliferation of microbial activities in soil. Results also revealed that addition of organic matter further increased the microbial biomass carbon in soil. This is due to supply of energy rich materials for the growth and activities of microorganisms prevail in soil (Kanchikerimath and Singh, 2001). Treatment $\mathrm{T}_{5}$ and $\mathrm{T}_{3}$ are statistically at par with each other. Results clearly pointed out that biomass carbon was increased within 15 days very sharply and reached a near constant level after 30 days of incubation (Paul and Solaiman, 2004). In $T_{5}, T_{3}$ and $T_{4}$ treatments $M B C$ results showed significant results for all the incubation stages due to balanced fertilization which help to proliferate microbial growth and in turn higher MBC in organic matter added under treatments. Results of treatments and stages of sampling as well as their interactions differ significantly. 


\section{Available S}

Figure 1 represent changes in the amount of available $\mathrm{S}$ in soil treated with different inorganic and organic fertilizers. Higher amount of available $\mathrm{S}$ accumulated in soil due to mineralization of higher amount organic matter present in soil. However, the accumulation of mineralized sulphur in soil depends upon treatment combinations (Saren and Saha, 2018). Available S slightly decreased from 30 to 60 day period of incubation and then again increased in the last stage of incubation except in treatment $T_{3}$ and $\mathrm{T}_{4}$. Statistical analysis of the results, however, showed that the treatments differ significantly with each other. The stages of sampling as well as interaction between stages and treatments are also significant.

\section{Available B}

Available boron increased on $30^{\text {th }}$ (except in control, $\mathrm{T}_{0}$ ), thereafter showed a decreasing trend upto $90^{\text {th }}$ day of incubation (Figure 2). Application of organic matter significantly increased the availability of boron in soil along with organic matter and full dose of NPK. This is due to release of boron from adsorbed phase to soil solution form which is available to plants Berger, 1962). Application of boron in combination with NPK, FYM and $\mathrm{S}$ (treatment $\mathrm{T}_{5}$ ) increased the availability of B in soil. Gupta (1979) also observed that the application of FYM resulted in an increase in the content of the boron in the soil. The similar finding was also reported Yadav (2016). Data are statistically significant with respect to treatments and stages of sampling as well as their interaction.

\section{Application of research}

The results of the laboratory experiment can be extrapolated under field condition. The results of field experiment may be then implemented in vast area of alluvial soil of West Bengal to raise mustard crop with high yield.

\section{References}

Abraham, T. and Lal, R. B. (2003). Strategies for INM technology in sustainable edaphocultivar management for a legume based (black gram-wheat-greengram) cropping system for the inceptisols in the NEPZ. Crop Res., 26(1):17-25

Antil, R.S. and Singh, M. (2007). Effects of organic manures and fertilizers on organic matter and nutrient status of the soil. Arch. Agron. Soil Sc. 53: 519-528

Arbad, B. K. and Ismail, S. (2011). Effects of intergrated nutrient management on soyabean (Glycine max) safflower (Carthamus tinctorius) cropping system. Indian J. agron, 56:340-345.

Benbi, D.K., Biswas, C.R., Bawa, S.S. and Kumar, K., (2007). Influence of farmyard manure, inorganic fertilizers and weed control practices on same soil physical properties in a long-term experiment, Soil use and Management, 14(1): 52-54.

Baruah, T.C. and Barthakur, H,P.,(1997). A text book of soil analysis, Vikash Publishing House Pvt. Ltd., Bangalore.334

Berger, K.C.,(1962). Micronutrient deficiencies in United States, J. Agric. Food Chem 10:148-181

Bremner, J. M and Keeney, D.R.(1965). Steam distillation methods for determination of ammonium, nitrate, and nitrite. Anal. Chim. Acta 32:485-95.

Buresh, R.J., Smithson, R.C. and Hcllums, D.T. (1997). Building soil phosphorus capital in Africa. In: replenishing soil fertility in Africa, Buresh, R.J., Sanchey, P.A., Calhoun., F., Eds., SSSA special publ. 51., SSSA: Madison, Wisconsin, USA, 97-109

Burger, M. and Venterea, R.T. (2008). Nitrogen immobilization and mineralization kinetics in cattle, hog and turkey manure applied to soil. Soil Sc. Soc. Am. J. 72: 1570-1579

Casy A, Schmidt. And Mark W, Clark. (2012). 
Efficacy of gentrification wall to treat continuously high nitrate loads. Journal ecological engineering., 42: 203-211.

Chesnin L, Yien, C.H.(1951). Turbidimetric determination of Available sulphate. Proc. Soil Sci. Soc. Amer., 15:149-151.

Clark, M.S., Horwarth, W.R., Shennan, C. and Scow, K.M., (1998), Changes in Soil Chemicals Properties Resulting from Organic and Low- Input Farming practices, Agronomy Journal, 90: 662-671

Fraser, P.M., Haynes, R.J. and Williams, P.H.,(1994). Effects of pasture improvement and cultivation on microbial biomass, enzyme activity and composition and size of earth worm populations, Biol. Fertil. Soils, 17:185-190

Gupta, U.C. (1979): some factors affecting the determination of hot water soluble boron from podzol soils using Azomethine-H. Can. J Soil Science, 59:241-247

Jackson, M.L. (1973). Soil Chemical Analysis. Prentice Hall of India. Pvt. Ltd., New Delhi : 497-503.

Joergensen, R.G. (1995): microbial biomass In: Alef, K., Nannipieri, P. (eds) Methods in Applied Microbiology and BioChemistry, Academic Press,: 382-386

Kanchikerimath, M. and Singh, D., (2001). Soil organic matter and biological properties after 26 years of maize-wheat-cowpea cropping affected by manure and fertilization in a cambisol in semiarid region of India, Agric. Ecosyst. Environ., 86:155-162

Naik, P., Barik, A., Baliarsingh, A., Pati, P., Santra., G.H., Swain, D., Nanda, A.Effect of Sulfur and Boron on growth and yield of Mustard (Brassica jauncea L.) Environment\& Ecology. 34(4A): 19531957.

Olsen, S.R., Cole, C.V., Watanable, F.S. and Rean, L.A.(1954). Estimation of available phpsphorus in soils by extraction with sodium bicarbonate. United States Department of Agriculture Circular 939.

Palm, C. A., Gachengo, C. N., Delve, R. J., Cadisch, G. and Giller, K. E. (2001). Organic inputs for soil fertility management in tropical agroecosystems: Application of an organic resource database. Agric. Ecosyst. Environ. 83: 2742.

Paul, G.C. and Solaiman, A.R.M.(2004). Changes of microbial biomass carbon and nitrogen in upland sugarcane soil amended with different organic materials. Common. Soil Sci. Anal., 35(17/18): 2433-2447

Piper, C.S. (1966).Soil and Plant Analysis. Inter Science Publications. New York

Premi, O.P. (2003). Integrated nutrient supply for sustainable rice production in an acid alfisol. Indian J. agric. Res., 37(2):132-135

Saren, S. and Saha, D. (2018). Dynamics of sulphur in a typic haplaquept soil in relation to rapeseed. J. Indian Chem. Soc. 95: 1-6.

Sarkar, S. and Singh S.R.(1997). Integrated nutrient management in relation to soil fertility and yield sustainability under dry land farming. Indian J. Agric. Sci., 67(9) : 431-433

Schollenberger, C.J. and Simon, R.H. (1945) Determination of exchange capacity and exchangeable bases in soil. Soil Sci, 59: 13-24.

Stevenson, F.J. (1996) Nitrogen-Organic forms. In Sparks, D.L. (ed). Methods of soil Analysis; Chemical methods part 3. Soil Sci. Am. Book Series No 5, ASA-SSSA, Madison, NI: 1185-1200.

USDA (1975) A basic system of soil classification for making and interpreting soil surveye. Soil taxonomy., Washington, D. C pp 754.

Walkley, A and Black, I.A. (1934). An examination of the Degtjareff method for determining organic Carbon in Soils. Effect of variations in Digestion conditions and of inorganic soil constituents. Soil Sci. 63: 251-263.

Walter T. Federar (1927). Experimental design, Theory and Application, Oxford and IBH Pub. Co. Calcutta.

Woldendrop, J.W. and Loanbrook, H.J., (1989). Activity of nitrifiers in relation to nitrogen nutrition of plants in natural ecosystem. 115(2): 218-228. 
Wolf, B. (1971). The determination of boron in soil extracts, plant materials, compost, manures, water and nutrient solution. Commun. Soil. Sci. Plant Anal. 2:363-374
(2016). Effect of boron on yield attributes, seed yield and oil content of mustard (Brassica juncea L.) on an Inceptisol. J. Indian Soc. Soil Sci. 64:91-96.

\section{How to cite this article:}

Tapas Kumar Halder, Ajit Kumar Dolui and Dipankar Saha. 2020. Monitoring of Nutrient Status in an Alluvial Soil Amended with Different Inorganic and Organic Fertilizers. Int.J.Curr.Microbiol.App.Sci. 9(05): 3465-3473. doi: https://doi.org/10.20546/ijcmas.2020.905.411 